\title{
Luce Irigaray e a Psicanálise: uma crítica feminista
}

\section{Luce Irigaray and Psychoanalysis: a feminist critique}

\author{
Rafael Kalaf Cossi ${ }^{1}$
}

\begin{abstract}
Resumo
Este trabalho visa expor o debate que Luce Irigaray trava com a Psicanálise. Inicialmente, contextualiza sua obra no universo feminista. Irigaray compõe a vertente francesa que, nos anos 1970, dava destaque especial à linguagem. A autora defende que os desenvolvimentos freudianos referentes ao complexo de Édipo tomam o patriarcado como base e se edificam aos moldes falogocêntricos, a ser ratificado pela tendência estruturalista que fundamenta os preceitos do simbólico de Lacan - nessa conjuntura, a mulher não tem representação própria, sendo acomodada aos parâmetros masculinos que a inferiorizam. Como forma de reverter tal cenário, Irigaray propõe estratégias como a reconfiguração da relação mãe-filha e intervenções na linguagem, o que permitiria a fundação de uma escrita transgressiva a inscrever discursivamente o gozo feminino não refreável pelas balizas fálicas.
\end{abstract}

Palavras-chave: Irigaray. Feminismo. Psicanálise. Linguagem. Gozo.

\begin{abstract}
This paper aims to present the debate between Luce Irigaray and psychoanalysis. Initially, it contextualizes her work within the feminist field. Irigaray composes its French strand that, in the 1970s, gave prominence to language. She argues that the Freudian developments about Oedipus complex is based on patriarchy and are set up through phallogocentric resolutions, which would be ratified by the structuralist strand that underlies the Lacan's precepts of the Symbolic - in this conjuncture, the woman does not have its own representation, as she adapts to the male parameters that make her inferior. To disturb such situation, Irigaray proposes some strategies, such as the reconfiguration of the mother-daughter relation and interventions in language, which would make possible a transgressive writing type that would discursively inscribe female jouissance, which is not guided by the phallic parameters.
\end{abstract}

Keywords: Irigaray. Feminism. Psychoanalysis. Language. Jouissance.

\footnotetext{
${ }^{1}$ Universidade de São Paulo, São Paulo, SP, Brasil. E-mail: rkcossi@hotmail.com
} 


\section{Introdução}

O feminismo, em linhas gerais, pode ser segmentado em três grandes ondas (Lago, 2012):

o chamado "feminismo da igualdade" reivindicava paridade social e política com relação aos homens, em voga até a primeira metade do século XX - no contexto psicanalítico dos anos 1920, as produções de Karen Horney e Helene Deutch são emblemáticas, justamente por aclarar os supostos alicerces patriarcalistas que sustentavam o edifício freudiano do Édipo, que teria promulgado um lugar menor à mulher. $\mathrm{O}$ "feminismo das 'diferenças"”, segunda onda, vigora até a década de 1980. Intenciona-se enfatizar a mulher em si mesma e ressaltar suas especificidades - o corpo é posto estrategicamente em destaque, visando reverberar em meio discursivo, jurídico e econômico. A terceira onda feminista surge nos anos 1990 dessa vez, o dispositivo político que legitima certas manifestações da sexualidade, e refuta outras, é posto em xeque. A teoria queer é realçada sob os nomes de Butler e Preciado.

Grosso modo, na passagem da segunda para a terceira onda, o feminismo psicanalítico é seccionado. Amparada na teoria das relações de objeto, a vertente anglo-saxã pretendia desestruturar o patriarcado tencionando as reconfigurações familiares, as relações de trabalho e os pilares ideológicos dos gêneros. Por outro lado, a facção francesa condecorava a linguagem e seu impacto social - alegava-se que a recolocação da mulher no universo discursivo era truncada pelo patriarcado, eleito o inimigo a ser derrocado. É nesse contexto que nasce o "Movimento da escrita feminina" esboçado por
Hélène Cixous, Catherine Clément e Luce Irigaray: perseguia-se um tipo de escrita não prevista pelo que consideravam ser a ordem simbólica falocêntrica e que fosse movido por experiências do corpo, cuja regência, se transposta para o social, vislumbrava promover transformações.

$\mathrm{Na}$ empreitada de questionar a lógica da identidade e da diferença, o feminismo francês setentista se volta a Foucault, Derrida, Freud e Lacan, dentre outros. De Foucault, provém a desestabilização da unidade a-histórica atribuída ao corpo; de Derrida, a noção de falogocentrismo e a estratégia da desconstrução. Com a Psicanálise, a relação é conflituosa: se por um lado celebra a premissa do inconsciente como instância a minar a coerência do sujeito da Filosofia e a interpelação da linguagem na constituição do sujeito sexuado, por outro denuncia o que julgava serem as pilastras patriarcalistas que aparentemente firmariam seu arsenal teórico - daí também a utilidade das ideias derridianas.

"Logocentrismo" é o termo cunhado pelo filósofo para se referir à forma dominante da metafísica do pensamento ocidental, fundamentado na lógica da identidade, da exclusão e da polarização binária da diferença, tal como se dá a ver nos dipolos corpo/mente, natureza/cultura e homem/mulher, por exemplo, e que conduz à hierarquização de seus artigos, um a submeter o outro. Segundo Grosz (1989), o termo "desconstrução" contempla o procedimento que visa interrogar $O$ logocentrismo subjacente a certas obras literárias, a se estender às de Freud e Lacan; assim como 
preceitua táticas que objetivam escancarar seus pontos de vulnerabilidade e não identidade.

O neologismo "falogocentrismo" nasce da junção desse logocentrismo com o elemento "falo", que a Psicanálise definiria como o operador central da sexualidade - como se trata de um elemento que foi em larga escala tomado pelo feminismo como masculino, concedê-lo primazia levaria ao eclipsamento do sexo da mulher, homologando a gramática patriarcal. Grosz (1989, p. 29) sublinha que desconstrução é associada em Derrida a diversos nomes, como différance, "suplemento" e "Mulher", termos que reputa apontar ao mesmo tempo para a falta e o desmedido, arroubo que estorva o sujeito como senhor do seu discurso: "Mulher representa uma resistência, um lócus de excesso dentro de textos logocêntricos/falocêntricos, funcionando como um ponto no qual o texto se volta contra si próprio" (Grosz, 1989, p. 33), problematizando a diferença e as identidades sexuais tais como sistematizadas em uma estruturação binária na roupagem patriarcalista. Assimilar a noção de différance também marca uma diferença no íntimo desse feminismo francês - não é a igualdade com os homens que ele espreita, nem uma possível definição do que seria a mulher; pelo contrário, o que se pretende é frustrar tal destino. Esse é o ambiente feminista de Irigaray.

Luce Irigaray (1932-) é filósofa, linguista e psicanalista, cuja obra, imersa na história da filosofia, vai dos pré-socráticos até os pósestruturalistas, ao passo que mantém um vínculo incessantemente conturbado com Freud e Lacan.

Em 24 de março de 1965, ela participa ativamente, ao lado de Jean Oury e Jean-Paul Valabrega, do debate fechado intitulado "A propósito da comunicação de Serge Leclaire de
1965: Sobre o nome próprio", a constar no Seminário XII de Lacan - que, por sinal, ao lado de Leclaire, também fez parte da discussão que girava em torno do estatuto do nome, do nome de família, das suas relações com o imaginário, o simbólico e o corpo. Irigaray também se faz presente no Seminário XIV, na lição de 1 de fevereiro de 1966, agora junto de Lucien Mélèze e Jenny Aubry, em interlocução com Jakobson e Lacan. Ela levanta questões sobre a diferença entre sujeito do enunciado, sujeito da enunciação e shifter. Mas o tom colaborativo e cordial entre Irigaray e o lacanismo se encerra anos depois. A publicação de seu primeiro livro, fruto de sua tese de doutorado - Speculum: de l'autre femme, de 1974 -, que lhe deu notoriedade nos círculos feministas, acabou resultando na sua expulsão da École Freudienne de Paris, fundada por Lacan, e a impediu de dar continuidade ao ensino universitário que empreendia em Vincennes. De toda forma, seu trabalho teve o devido reconhecimento dentro e fora da França - é imensa a influência que exerceu sobre Butler e Braidotti, por exemplo. Preciado (2002, p. 36) chega a homenageá-la ao denominar os corpos transmutados pela tecnologia, estandarte de seu manifesto contrassexual, de wittigs.

Delatar a espoliação da mulher põe em xeque não só questões econômicas, legais e morais, mas, sobretudo, como o sistema patriarcal formata a linguagem, na qual se assenta nossa ordem cultural e social como um domínio monopolizado pelo homem. Irigaray tem o projeto de iluminar o feminino entendido como o ponto cego do discurso filosófico, que também estaria na base do psicanalítico conformado ao falogocentrismo, segundo a autora. 
A polarização binária da diferença faria parte do maquinário patriarcal, no interior do qual o homem é identificado com o significante fálico e a mulher não é passível de representação por conta própria. Consequentemente, a mulher não seria entendida em seus próprios termos, mas sempre a partir do que o homem dita o que ela deve ser, no caso, o negativo dele. Repete-se então toda uma tradição: se ao homem concerne a nobreza do mundo das ideias, a figura da mulher é associada à matéria, carne e natureza, só lhe sendo possível aproximar-se do status de sujeito ao assimilar aspectos da masculinidade, e não a partir de suas especificidades.

A proposta de Irigaray de derrocada do falocentrismo também teria repercussão na clínica psicanalítica em termos práticos; incidiria na qualidade da escuta do analista e no manejo da transferência, tal como elabora nos textos "The limits of transference" e "The gesture of psychoanalysis" - ambos publicados em Whitford (1991).

Irigaray é veementemente avessa à estagnação da Psicanálise institucionalizada. Em seu entender, havia uma recusa da Psicanálise de analisar politicamente suas estruturas, o que endossaria, segundo a autora, uma cega submissão ao discurso normativo de poder. De acordo com Gallop (1982, pp. 94-95), tal circunstância descrita por Irigaray teria reflexos inclusive na prática clínica dos psicanalistas, que tenderiam a submeter seus pacientes à mesma relação de subserviência que aqueles manteriam com seus mestres de escola, assujeitando-os aos significantes deles.

Ainda nessa perspectiva de análise da política interna à própria instituição psicanalítica,
Lisa Jardine (in Brennan, 1997) alega que as mulheres não tinham voz lá, que elas não participavam da transmissão da teoria naquela época: atestaria tratar-se de um espaço também hierarquicamente dominado pelos homens, o que o afastamento de Irigaray parecia confirmar: "a mulher analista deixa o seminário do Mestre e começa a produzir um modelo teórico de um imaginário feminino alternativo" (Jardine, in Brennan, 1997, p. 94). Ou seja, o passo dado pelo feminismo francês era político, na medida em que angariava um espaço outro também no âmago da geração da teoria. O social e o simbólico deveriam ser revistos para recolher o corpo feminino, assim como o corpo da teoria psicanalítica deveria ser modificado ou acrescido de elementos para recebê-lo.

Neste texto, limitar-nos-emos à relação que Irigaray estabelece com a Psicanálise. Ela se empenha em denunciar o que intuía serem os suportes masculinos e opressores que apoiam as obras de Freud e Lacan, fruto do que ela considerava uma incorporação acrítica da estrutura do pensamento falogocêntrico. Como forma de combater tal sistema, Irigaray desenvolve um método amparado na reconfiguração da relação mãe-filha, na noção de mimesis, em inovações teóricas como a "simbolização dos dois lábios", chegando até a propor uma latente subversão no campo da linguagem sustentada na ideia de conquista do imaginário e abatimento do simbólico, correlata à operação de outra lógica a conduzir uma escrita revolucionária, e que corre em paralelo às suas pesquisas sobre a dinâmica dos fluidos e o exercício do toque. 


\section{Freud e o sexo uno}

Em sua crítica a Freud, Irigaray se guarnece dos trabalhos de Melanie Klein, Ernest Jones, Helene Deutsch, Jeanne Lampl-de Groot, autores que valorizaram a fase pré-edípica, período do curso sexual que tais autores concebiam como ainda não comandado pelo falicismo. Também foi marcada por Karen Horney e o enfoque dado ao papel dos fatores socioculturais em repercussão na sexualidade.

Para Irigaray, a metafísica de Platão teria subsidiado a concepção ocidental de diferença sexual, que acabou achatando o imaginário feminino ao reduzi-lo à equação mãe-mulher. A economia masculina prevalecente seria posta ao lado do logos filosófico, restringindo tudo à economia do mesmo ou ao pensamento simétrico. Tudo passa a ser medido a partir do homem, único sujeito representado filosoficamente. A mulher é um não-homem. Nesse sentido, se o discurso filosófico apresenta um estilo lógico, coerente portanto, masculino -, à mulher seriam compilados os atributos contrários, como irracionalidade e inconsciência. O que Irigaray considerava ser o processo de construção do homem como sujeito exigiria, segundo ela, o bloqueio da mulher a tal condição. À mulher só seria possível acessar o lugar de sujeito se "importasse" elementos, parâmetros ou processos próprios ao masculino - então, é como se a diferença sexual não existisse. No fim das contas, só haveria um sexo; a mulher seria o outro excluído - daí a insistência de Irigaray em que o movimento feminista repise a diferença sexual, que levaria à concepção de mais de um sexo.

Freud, segundo a autora, seria herdeiro dessa tradição filosófica pautada na perspectiva masculina ao propor que, embora os corpos sejam distintos anatomicamente, tal discernimento estaria encoberto pela primazia fálica até o fim do complexo do Édipo. Além do mais, a libido é única, masculina: "A diferença sexual é uma derivação da problemática da mesmitude" (Irigaray, 1974/1985, p. 26).

É o que Irigaray irá criticar, lembrando que tais premissas conduzirão às definições freudianas da sexualidade feminina sob tais expressões: inveja do pênis, superego fraco, menor senso de justiça, menos interesses sociais e menor capacidade sublimatória. É como se a mulher fosse fruto de um desenvolvimento insuficiente ou deformado quando comparada, sob os mesmos critérios e o mesmo percurso edípico, ao que se dá com o homem.

É pelo fato de a mulher ser entendida como ontologicamente irrepresentável na época de Freud, para Irigaray, que se passou a dizer, como Beauvoir, que não se nasce mulher, mas torna-se uma. Mas o que ela seria antes dessa "conquista"? "Nada" (Irigaray, 1974/1985, p. 25), só um menino menor cuja libido deve ser reprimida em direção ao tornar-se mulher.

Até então, a menina teria sido um pequeno menino com certos atributos morfológicos a menos. Ela vive de maneira masculina: excita-se ativamente com o clitóris, uma "espécie" de pênis - aproximação que, por sinal, nunca é bem superada, o que a levaria sempre a buscar substitutos, a ficar na dependência de alguém que a aliviaria da dor de não o possuir, - e ativamente toma a mãe como objeto de amor. Ao postular que o que caracterizaria a mulher seria a inveja do pênis, Freud, segundo Irigaray (1974/1985, p. 63), não estaria pautado em uma heterogeneidade, mas 
sim num tipo de negatividade: não é que ela teria outro órgão ou outro sexo, mas sim um não-sexo ou não-órgão. Definir a sexualidade feminina desse modo, para a feminista, seria como uma forma de dominação, uma estratégia que visaria perpetuar o poder nas mãos dos homens $\mathrm{e}$ aniquilar eventuais ameaças, caso a mulher acessasse alguma categoria de representação a partir do que lhe é próprio.

Em sua leitura, Freud operaria dicotomicamente e, a partir desse pensamento simétrico, a feminilidade só poderia ser um reflexo negativamente equacionado à masculinidade. Assim, Irigaray argumenta que para que o homem domine essa economia e o processo de especularização seja bem-sucedido, é forçosa a produção de um “outro”, seu binário negativo, a ser diferenciado dele e hierarquicamente subjugado. Segundo a autora,

[a especularização] é uma intervenção necessária, exigida por esses efeitos de negação que resultam de/ou postas em movimento através da censura do feminino, através do qual o feminino será admitido e obrigado a assumir tais posições: ser/tornar-se; ter/não ter sexo (órgão); fálico/não-fálico; pênis/clitóris ou mesmo pênis/vagina; mais/menos; claramente representável/continente negro; logos/silêncio on tagarelice; desejo pela mãe/desejo de ser mãe. (Irigaray, 1974/1985, p. 22, trad. nossa)

Irigaray (1974/1985, pp. 29-30) aponta que não há uma discussão em Freud a respeito de um suposto estágio da vulva, da vagina ou de um estágio uterino na discussão da sexualidade feminina, o que seria tributário de uma especificidade da mulher; ou da peculiaridade do prazer da vagina ou do toque dos seios e dos lábios. Por que a masturbação da menina só é relativa ao clitóris? Se Freud, na leitura de Irigaray, não diz nada acerca de outros componentes do órgão genital feminino e de outras partes sensivelmente erogeneizadas, ele amputaria certas regiões da genitália feminina que em tese teriam menor potencial erótico. Fica difícil entender por que, em Freud, a passagem do clitóris para a vagina como principal zona erógena é relevante, e Irigaray sugere que o motivo talvez seja a vagina ser uma seção do aparelho genital feminino indispensável para o prazer masculino no ato sexual. Ademais, se a castração, no complexo de Édipo, é a de um órgão do menino, e não uma castração "dela", que diga respeito à perda de algo do corpo dela. Assim sendo, para Irigaray, a genitália feminina só poderia ser percebida com horror, associada à falta ou a uma falha na constituição do sexo ideal, o masculino - dai a inveja do pênis ser o representante do desejo feminino de acionar a ordem simbólica; e dessa maneira não feminina, entrar no discurso.

A castração viabilizaria à mulher somente uma "saída honrosa", a mascarada, recurso esse que Irigaray infere proporcionar algum prazer tipicamente feminino (Irigaray, 1974/1985, p. 114). Para ela, a construção da máscara se edificaria a partir dos valores que os homens julgam importantes para uma mulher. Ela depreende se tratar de um processo fálico e que, no seu desenrolar, conclamaria que a mulher descarte o que, de fato, lhe seria "seu" para 
corresponder aos padrões masculinos que impõe como ela deve se dar a ver.

Irigaray defende que a castração feminina não poderia ser pensada a partir da mesma referência válida para o menino. Ela sugere que a castração na mulher deva ser encarada como o impedimento de representar ou simbolizar a relação inicial com a mãe (período pré-edípico). Talvez sua "mal resolvida" castração, e a concomitante dificuldade de entrar como sujeito nos sistemas simbólicos, tenha a ver com a impossibilidade de metaforizar aquele desejo original fruto da relação mãe-filha. Uma vez que Irigaray interpreta que a premissa fálica freudiana e a castração são universais, só cabe à menina se submeter às mesmas metáforas fálicas que o menino; só restaria a ela imitá-lo e fazer equivaler seu desejo pela mãe com o desejo por uma mulher, e não a um desejar como mulher (a primeira saída pressupõe que as imagens de mãe e de mulher se condensam no mesmo ser; a segunda, não). A não significação da mulher nessa relação mãe-filha promoveria a depreciação da mãe - e de todas as mulheres, já que castradas - aos olhos da menina (Irigaray, 1974/1985, pp. 83-84).

Outro ponto muito contestado por Irigaray é a dicotomia ativo/masculino e passivo/feminino que ela enxerga estar impressa nos escritos freudianos da diferença sexual. Em Freud, na fase pré-edípica, a menina seria como um menino tacanho. No estágio sádico-anal, não haveria diferenciação entre homem e mulher - só masculinidade - nem entre atividade e passividade. Seu clitóris é fálico e ativo. Ela tem de abandonar o investimento nesse órgão sexual (e seu objeto de amor inicial, a mãe) para desembocar na feminilidade normal, abalizada pela erotização da vagina. Caso contrário, seu destino será a neurose ou a masculinização. Irigaray aponta que é só nesse momento posterior que, talvez por imposição de valores culturais, a menina tenha de abrir mão de seu caráter ativo em prol da feminilidade passiva que é esperada dela. Mas a mulher seria sempre passiva? - segue questionando a autora. Não, só em um caso ela não é: ela "escolhe" ativamente a posição masoquista, tal como se leria em Freud. Para Irigaray (1974/1985, pp.19-20), ela não teria opção: como deve suprimir sua agressividade sob um imperativo social, já que deve ser afetuosa e dócil, a mulher converteria sua libido em impulsos masoquistas, erotizando tal tendência destrutiva.

Neurótica, masculinizada ou feminina masoquista. Irigaray conclui de seu exame que, para Freud, toda e qualquer mulher é patologizável, por ser mulher - e que patologizar a mulher seria uma forma de adaptá-la à sociedade masculina (Irigaray, /1977/1985, p. 73). Nem a maternidade - que, em Freud, seria a chancela definitiva do feminino edipicamente dignificado - escaparia desse raciocínio.

$\mathrm{Na}$ acepção de Irigaray, a feminilidade, marcada pela inveja do pênis, tenderia a desaparecer com a maternidade. Fazer-se de mãe, tomar o filho como substituto do pênis ausente, por ser um recurso fálico, não seria feminino (Irigaray, 1974/1985, pp. 77-78).

Então, seria só por meio de repetições, reiterações de representações fálicas, inscritas no e pelo masculino, que ela entraria no universo discursivo do Mesmo. Uma vez que, na sua visão, como a mulher não seria passível de se inscrever na linguagem por si, ela nada teria a dizer propriamente sobre seu prazer e angústias. $\mathrm{Na}$ sequência, só restaria aos seus sintomas, 
hieróglifos indecifráveis, a inscrição no corpo: a mulher permaneceria ligada diretamente ao corpo - nesse caso, a somatizações enigmáticas e ao teatro -, sempre como objeto misterioso que se presta à investigação do homem: mulher continente negro.

Para Irigaray, todo esse cenário social, econômico e representacional ao qual a mulher é relegada seria, necessariamente, indutor de sofrimento. A feminista sugere que muitas das moléstias da mulher são provocadas pelo fato de que, para ter inteligibilidade, ela tenha de reprimir sua feminilidade e falar a "língua dos homens".

Nesse sentido, e essa nos parece ser a principal reprimenda de Irigaray a Freud, ela defende que os desenvolvimentos freudianos referentes à diferença sexual não deveriam ser sondados como atemporais, mas como resultado do caldo histórico e cultural em que estava embebido, uma cultura "hommo-sexual" (Irigaray, 1974/1985, p. 103) dirigida por uma disciplina patriarcalista de base vitoriana: "O problema é que ele [Freud] falha por não investigar os fatores históricos que regem os dados com os quais ele estava lidando" (Irigaray, 1977/1985, p. 70). Para ela, Freud não teria se dado conta de que havia a tendência, em sua época, de tomar a anatomia como critério de verdade científica irrefutável e universal; ele não teria reconhecido se tratar somente daquilo que ela supunha ser um discurso dentre outros a prevalecer em determinado tempo histórico. A autora acusa Freud de não questionar os fatores culturais que exigiriam que a mulher abafasse sua libido no seu caminho rumo à feminilidade.

Para falar da mulher, Freud teria recorrido aos elementos dele e, nessa comparação, a mulher sempre seria maculada. Para Irigaray, a sexualidade feminina não deveria ser circunscrita desde esse modelo que descreveu como sendo de "um" sexo. Seria graças a essa presumida manobra histórica-discursiva que as mulheres sejam vistas pejorativamente.

\section{Lacan e o simbólico interditor}

Segundo Irigaray, no processo de constituição do ego corporal do estágio do espelho, a função simbólica decorrente da entrada do sujeito no campo da linguagem é imprescindível. A formação da imagem do corpo depende da autenticação do Outro. Contudo - e aqui Irigaray se destaca de Lacan -, notadamente marcada pela cultura ocidental, tal construção imaginária tem a tendência de "ir contra" o corpo das mulheres: o corpo imaginário que domina o que se entende por corpo é o do homem. Identidade e unidade seriam relacionadas à anatomia masculina - a depreciação da mulher faria com que a constituição de sua imagem corporal sexuada não se desse da mesma forma que a dele. Consequentemente, para a autora, as partes do corpo feminino que denunciam a que sexo pertence tenderiam a ser menos investidas libidinalmente.

Apesar dessa repreensão ao imaginário do corpo em Lacan, o principal alvo de Irigaray é o registro simbólico. Para ela, Lacan - mesmo tendo ao seu dispor instrumentos científicos mais refinados, como a linguística estrutural de Saussure - padeceria do mesmo erro de Freud ao adotar o modelo de "um" sexo, só que analisando a diferença sexual se munindo dos recursos simbólicos da linguagem. Lacan teria mantido a 
mulher presa a uma versão negativa do Édipo e às garras do falo, agora alçado ao status de significante.

Segundo Irigaray, em "Diretrizes para um congresso sobre a sexualidade feminina", Lacan teve o mérito de ter reaberto o debate a respeito da sexualidade da mulher. Evocou novos desenvolvimentos fisiológicos referentes ao "sexo cromossômico", ao "sexo hormonal", ao privilégio libidinal do hormônio masculino; aclarou a ignorância que ainda imperava sobre a natureza do orgasmo vaginal e o papel do clitóris no investimento nas diferentes zonas erógenas (Irigaray, 1977/1985, p. 60). Mas, e é a partir daqui que Irigaray passa a criticá-lo, Lacan teria apontado o quanto é fundamental não negligenciar a perspectiva estrutural que já estaria implícita no complexo de castração freudiano. Para se ter uma leitura justa do Édipo, há de se levar em conta os registros simbólico, imaginário e real. Contudo, para Irigaray, a tradição lacaniana não os balanceou devidamente e o registro simbólico tomou uma dimensão dilatada demais e uma interpretação inadequada.

O Lacan dos anos 1950 especifica que o que está em jogo na castração é a operação da metáfora paterna que impede que mãe e filho satisfaçam seus desejos de completude fálica. $\mathrm{O}$ desejo passa a ser simbolizado por intermédio da linguagem: a necessidade é separada da demanda, fazendo com que o falo seja o significante da falta resultante desse processo, o significante do desejo. À mulher cabe "ser o falo". Para tanto, ela deve renunciar a uma parcela essencial da sua feminilidade para a construção, processo fálico, da mascarada. Então, para Irigaray, seria sendo o que ela não é que ela pede para, ao mesmo tempo, ser desejada e amada. Já do lado do homem, trata- se de "ter o falo". Ela só encontraria o significante do seu desejo no corpo do homem, que hipoteticamente o tem, renovando, na visão de Irigaray, o freudismo mais vulgar.

Essa formulação de uma dialética das relações, sexualizadas pela função fálica, de forma alguma contradiz a manutenção do complexo de castração da menina de Freud (ou seja, sua falta ou não-ter falo) e sua subsequente entrada no complexo de Édipo - ou seu desejo de obter o falo de quem é suposto o ter, o pai. Dessa forma, a importância da "inveja do pênis" da mulher não é posta em questão, mas é elaborada mais profundamente em sua dimensão estrutural. (Irigaray, 1977/1985, p. 62, trad. nossa)

Para Irigaray, o falo, mesmo como significante privilegiado do simbólico, ainda conservaria uma relação insuperável com o pênis; serviria como um instrumento teórico mais aprimorado a reafirmar a submissão e a inferiorização da mulher. Professar a diferença a contar de um referente único - e que, ainda, é historicamente masculino, no ponto de vista da autora, seria inaceitável. Além do mais, ela reprova Lacan em diversos momentos por considerar que o simbólico "dele" é um registro a-histórico e imutável, que refuta rearranjos. Para Irigaray, a linguagem deve ser estimada como maleável, em fluxo e entregue a relações de poder. Se a cultura ocidental, incluída aí a Psicanálise, na perspectiva da feminista, não entende as mulheres, é porque insiste em manter os mesmos paradigmas falogocêntricos, regidos por leis que se querem totalizantes. 
Outro argumento em prol de uma suposta orientação fálica patriarcal inerente ao lacanismo se daria a ver tanto no peso concedido quanto na própria nomenclatura de conceitos nucleares: Nome-do-Pai; lei do Pai; metáfora paterna. A mulher continuaria sendo associada ao outro, mesmo que ao Outro da linguagem campo a partir do qual o sujeito (homem) se faria reconhecer como tal: ela servindo como "a matriz, útero para os significantes do sujeito" (Irigaray,1977/1985, p. 101).

Quando discorre ácida e longamente sobre Deus e o Pai na Filosofia, Irigaray parece açoitar o Nome-do-Pai lacaniano, atacando o que julga ser sua onipresença, transcendência e ditadura, ao afirmar que "o sujeito do discurso é o pai" (Irigaray, 1974/1985, p. 308): um pai que não pode ser visto, que nunca tomará vida e vir a existir; que não tem mortalidade, sempre tendo sido pura especulação; um pai cujo efeito, dentre outros, é o de operar a "divisão em dois gêneros, dois tipos de recurso de especula(riza)ção" (Irigaray, 1974/1985, p. 308). O pai, segundo a autora, é límpida especula(riza)ção, é especulação e especular, refletindo o Mesmo, o ser e o um. As fantasias do Ser, manipuláveis e fetichizadas, são frutos da père-version que compõe as representações. "A palavra do Pai domina as organizações" (Irigaray, 1974/1985, p. 313), promove a entrada do filho no discurso da Filosofia e não aceita nenhuma particularização da forma - é o que estabelece a economia das representações e produz um ideal de gozo, delibera Irigaray.

Como tal, o Pai, imutável e idêntico a si, nesse prisma, está fora das recolocações da história, ao passo que é tomado como fundamento da lei, o que é inadmissível para ela.

Irigaray ainda elucubra se a foraclusão, mecanismo típico da psicose, poderia estar em execução no trato da mulher, haja vista sua presumida expulsão do universo da linguagem. Sem significante do "seu desejo" ou imagens válidas do seu corpo, "o que a condenaria à psicose ou, na melhor das hipóteses, à histeria, pela falta - censura? foraclusão? repressão? - de um significante valoroso de seu desejo 'primeiro' ou de seus órgãos sexuais” (Irigaray, 1974/1985, p. 55). Para Irigaray, o aparato teórico de Lacan rechaçaria a mulher à patologia pelo fato de ser mulher, tal como em Freud, mas agora assumindo a linguagem como terreno. $\mathrm{O}$ mesmo se daria, segundo a autora, a partir das teses lacanianas concernentes ao gozo.

Se Irigaray incorpora tal conceito por acreditar que, dentre outras alternativas, seria dando vazão a ele, vencendo o que o constrange, que se teria acesso à especificidade feminina, ela continua tecendo suas repreensões a Lacan. No capítulo Cosi fan tutti (Irigaray, 1977/1985), tomando como referência o Seminário XX, Irigaray problematiza sua caracterização do gozo feminino como inefável, suplementar à gerência fálica ou além da linguagem - Irigaray interpreta tais descrições como uma sentença de exclusão do discurso. A mulher é não toda; todo é o homem, fálico. Como nada é possível de ser declarado sobre o seu gozo, a mulher se mantém como alguém que não tem nada a pronunciar sobre o que seria o mais próprio de si, na percepção irigarayana. O artifício ardiloso seria a inversão: “À objeção de que esse discurso talvez seja não- 
todo [pas tout], a resposta será que elas que são nãotodas [pas toutes]" (Irigaray, 1977/1985, p. 88).

Com outros recursos, mas com a mesma força de denúncia dessa pressuposta estagnação paradigmática, em "The mechanics of "fluids", Irigaray $(1977 / 1985)$ reputa que toda ciência pode ser pensada a partir da categoria do sólido, coligada à masculinidade; e a dos fluidos, à feminilidade. O gozo da mulher, nas suas palavras, é líquido, indefinido e ilimitado (Irigaray, 1977/1985, p. 229), inabarcável pelos parâmetros falogocêntricos. O sexo da mulher não é uno; seu gozo explode em várias partes do seu corpo, espelhado de maneira multifacetada, num jogo polimórfico de reflexos, contrário à unidade de especularização - reflexo reto, simétrico e exato do homem, correspondente à restrição que seu sexo unilateral the inflige, discrimina Irigaray.

A mulher não é aberta nem fechada: é indeterminada, tem uma forma nunca completa (Irigaray, 1974/1985, p. 229). Não é infinita, mas também não é uma unidade; não se pode dizer que ela é isso ou aquilo, o que está muito longe de se estatuir que ela é nada. Nenhum discurso daria conta da modalidade do seu desejo, nenhuma metáfora a completaria. Talvez a mulher se falicize para se relacionar com o homem, solidificando-se, de acordo com a feminista. Contudo, "o gozo da mulher excede tudo isso" (Irigaray, 1974/1985, p. 229), uma inundação sem contornos discerníveis. Gozo do corpo porque esse é seu espaço autêntico? Não, responde Irigaray, mas porque ele é exilado do discurso.

Tal desterro seria ratificado, segundo a autora, pelo veredito proclamado por Lacan reiteradas vezes em meio à ebulição do feminismo francês: "A mulher não existe". Decorre desse aforismo que as mulheres não formem conjunto, sendo tomadas uma a uma. "A mulher não existe, mas a linguagem existe. Que as mulheres não existem nessa linguagem - uma linguagem regida por um mestre, que ela ameaça - como uma espécie de 'realidade pré-discursiva'? - que perturba sua ordem" (Irigaray, 1977/1985, p. 89). Irigaray considera que o passo lacaniano de tomar as mulheres uma a uma comporia uma estratégia elaborada para impedi-las de conquistar uma representação discursiva ontológica, o que ameaçaria o império masculino.

Irigaray pensa que o falo, atuante sobre o gozo do corpo (do Outro), impõe-lhe “enumeração: um(a) por um(a). As mulheres serão apanhadas, testadas, uma a uma, para evitar o nonsense" (Irigaray, 1977/1985, p. 98). Localizar o não todo do discurso na mulher seria uma forma de fazer com que a falta do indizível fosse suportada, dispondo dessa substância chamada gozo. "A falha do acesso ao discursivo no corpo do Outro é transformada nos intervalos que separam as mulheres umas das outras" (Irigaray, $1977 / 1985$, p. 98). Nesse sentido, o uma a uma da mulher lacaniana seria uma manobra discursiva de poder com a intenção de enfraquecer seu conjunto na luta em se fazer escutar.

Como fora da linguagem, pertenceria ao universo do sensível. Seu corpo como marcado pelos significantes do homem, suporte das fantasias dele, onde seriam projetados seus objetos do desejo. "Nada a dizer desse gozo; portanto, não gozando. É como ela sustenta, para eles, a dupla função do impossível e do proibido" (Irigaray, 1977/1985, p. 96).

A sexualização da mulher se daria por uma imposição lógica a ser arcada pela função de objeto $a$, resto da produção das operações da linguagem, resto do corpo. Mas se trataria de um 
corpo sem órgãos, que não levaria em conta as zonas erógenas tão consagradas pela Psicanálise: "A geografia do prazer feminino não é escutada" (Irigaray, 1977/1985, p. 90). Afinal de contas, se só se pode gozar de uma parte do corpo do Outro, para a autora, o corpo da mulher deve ser fracionado, sempre recortado ao se configurar simbolicamente à maquinaria fantasística masculina.

Então, qual seria a ação decisiva a incluíla na sociedade dos homens? Acessar o objeto $a$ através do seu filho, mas: "Ah sim... ainda [encore] sem filhos, sem pai?” (Irigaray, 1977/1985, p. 94). Antiga equação mãe = mulher? Ela faz do homem, pai. Essa seria a única saída dentro da lei para o desejo feminino, na óptica de Irigaray - ao preço de que não seja um sujeito e que o discurso do homem, seu desejo e seu gozo não sejam importunados.

E mais, em sua apreciação, Lacan teria atrelado o gozo feminino à patologia.

Se o homem não tivesse que trabalhar e ela se nutrir para procriar, e ter de interromper seu (outro) gozo, ela poderia viver o amor indefinidamente - daí a dificuldade para ela de interromper o ato sexual. Ela sempre quer mais, ainda [encore] escreveu certo psicanalista (notadamente Jacques Lacan) que equacionou esse "mais" [toujours plus] a uma patologia. (Irigaray, 1977/1985, p. 64, trad. nossa)

Resumindo, para Irigaray, à mulher acoplam-se tais predicados: ela suporta o discurso, ao passo que está fora dele; seu gozo é não todo, estando em parte ausente de si mesma; não sujeito, cujo corpo deve ser talhado para caber na fantasia do homem. Se faltante, sobra a ela o "tamponamento" por meio do objeto a que é seu filho. "Não seria essa uma retomada mais refinada do postulado freudiano sobre a anatomia?" (Irigaray, 1977/1985, p. 102). Se “A mulher não existe", ela parece só entrar na relação sexual como mãe, discurso repisado na tradição filosófica do qual a Psicanálise não se desvencilharia. "Se há um discurso que demonstra isso, é o discurso analítico, por pôr em jogo, aqui, que a mulher só pode ser tomada como quoad matrem. A mulher só entra em jogo na relação sexual como mãe" (Irigaray, 1977/1985, p. 102) - essa passagem de Irigaray, que veladamente faz referência ao Lacan do Seminário XX, confirmaria, segundo a autora, a equação mãe $=$ mulher comumente levada a cabo pelo homem e que desta vez também se faria presente no discurso lacaniano. Com o risco de que, "sendo a relação sexual impossível, [...] se continue criando leis dessa própria impotência, e permanecer subjugando as mulheres" (Irigaray, 1977/1985, p. 105) - Irigaray interpela se a Psicanálise poderia lançar mão de outra lógica que dispensasse a suposta mestria masculina subterrânea que leva ao ofuscamento da mulher ao reduzi-la a mãe.

Vertendo-se outra vez ao uso que Lacan faz de instrumentos científicos novos à Psicanálise, Irigaray advoga estar subsumida a reatualização daquela antiga paridade.

A topologia do sujeito tal como é
definida por certos teóricos da
psicanálise (como Jacques Lacan) e


certos lógicos toma o solo ou substrato simbólico no qual o feminino está a serviço do sujeito masculino. Como o sujeito funciona de acordo com a banda de Moebius, indo de fora para dentro e de dentro para fora, sem mudar de borda, isso encerraria o ciclo do amor entre mãe e filha e entre as mulheres. Nessa clausura topológica, que não é aberta, o sujeito reprime-se, não é livre no que poderia vir a se tornar, a mulher é trancada neste “feminino-maternal", [...] e o que escapa a isso é repugnado. (Irigaray, 1984/1993, p. 105 , trad. nossa)

Contra esse presumido encarceramento do "sujeito feminino" à banda de Moebuis, na qual um lado corresponderia à mulher e o outro à mãe, figuras indissociáveis e indiscerníveis, Irigaray (1984/1993, p. 109) passa a ter em conta que a mulher deve construir um mundo em suas três dimensões.

A partir das considerações de Aristóteles, Irigaray assume que o lugar é, ao mesmo tempo, dentro e fora, ou que a mesma causa não atua da mesma forma dentro e fora, podendo haver uma reversão de envelopes - o que permite dispor do caráter de reversibilidade, torção e crossing-over [recroisement] (Irigaray, 1984/1993, p. 41). Isso nos soa como se Irigaray estivesse propondo que a diferença sexual fosse tratada a partir da topologia do cross-cap ou da garrafa de Klein. O sexo feminino como envoltório, que não se confunde com conteúdo nem continente - lugar que não é nem a matéria nem a forma, exclusivamente.

Todo esse esforço para fugir do binarismo, que, segundo a autora, participa da engrenagem do simbólico masculino associado a princípios dos sólidos, transporta-a aos estudos das propriedades dos fluidos - se referidos ao feminino, poderiam ser utilizados para inquirir sobre a diferença sexual e a imagem associada à mulher, contra a especula(riza)ção dual e monolítica que subentende, de acordo com a feminista, a estrutura do sujeito modelada pelo panorama do homem.

Irigaray, então, propaga a ideia de que as mulheres não seriam bem compatíveis com os quadros simbólicos, suas leis e seus sólidos princípios, mas sim próximas a uma agência que tenderia a perturbar tal ordem - no caso, o registro do real, que confunde as fronteiras e irrealiza ser capturado. Ao real, Irigaray confere a virtude fluida, que se comportaria como uma aporia na formalização matemática.

Qual seria importância disso para a Psicanálise? Metonímia (fluido) passaria a ter mais privilégio que a metáfora (quase sólido); desbancam-se dicotomias opositivas e categorias metalinguísticas. $\mathrm{O}$ sexo feminino seria um excesso à boa forma, essa que alicerça circuitos fechados como o princípio da constância ou a repetição do estado de equilíbrio. Irigaray chega a considerar que o próprio objeto a é do universo dos fluidos - ter sido relacionado a matérias sólidas, como às fezes, seria um exercício de dominação, tentativa de adaptá-los aos meandros da racionalidade. O objeto $a$ tenderia a apresentar o caráter de fluidos como urina, saliva, luz, onda, perfume, plasma (Irigaray, 1977/1985, p. 133). Fluido, $a$-forma, outra topológica: feminino.

\section{Para um plano de ataque}

E como viabilizar transformações políticas no universo dos sexos? Além da 
intervenção no campo da linguagem, Irigaray propõe que se reajuste a relação mãe-filha: a mãe transmitindo às filhas uma representação diferente do que seja uma mãe, patenteando ambos como sujeitos. Freud, na óptica de Irigaray, não enuncia que a identificação da menina com a mãe tem impacto menor que a do menino com o pai no fim do trajeto edípico. Ele dá a entender que estudar o período pré-edípico poderia ser um caminho promissor, mas obscuro, para a explicação da feminilidade (Freud, 1931/2010).

$\mathrm{O}$ dito comum de que as mulheres teriam dificuldades de se separar da mãe revelaria, para a autora, um sintoma da posição das mulheres na ordem simbólica, um estorvo para a simbolização primária dessa relação originária com a mãe - não se trata daquela ligação fusional entre mãe e filha prescrita por Chodorow, que criaria problemas para a identidade e a individuação da mulher. A mira medular da discussão de Irigaray é a ordem simbólica, que só disponibilizaria a ela o lugar de mãe. Outra representação da mulher permitiria que novas alianças fossem estabelecidas entre elas - amorosas, inclusive. Daí a proposta metafórica de retorno ao corpo da mãe efetuada por Irigaray como modo mais profícuo de acioná-lo por meio da linguagem, e que beneficiaria a filha levando-a a prestigiar seu próprio corpo.

Para Whitford (in Brennan, 1997), o grande projeto de Irigaray visa efetuar uma mudança na ordem simbólica, analisando como tal registro age e expondo seu aparente viés patriarcal. Como reverter esse quadro retratado pela feminista de inexistência de representações linguísticas ou simbólicas próprias da mulher? A estratégia que tenciona é de um ataque tanto horizontal quanto vertical: lutar por direitos, questionar normas sociais, rever aspectos econômicos e, como condição sine qua non, atuar nos meandros da linguagem.

O sujeito só passa a existir à medida que entra no campo da linguagem. Contudo, para Irigaray, a mulher não teria sua subjetividade reconhecida nessa esfera, e a Psicanálise não teria suplantado esse embaraço. A tática irigarayana para adulterar tal conjuntura não é simplesmente forjar meios de incluí-la, mas alterar a própria linguagem e o seu funcionamento que, segundo a autora, avança por dualidades nas quais um termo tem primazia sobre outro. Crucial ressaltar que para Irigaray não se trata de acomodar a mulher à linguagem - é a ordem simbólica, a estrutura sintática e morfológica da língua e as palavras que devem mudar.

Há de se examinar as operações gramaticais de cada figura de discurso - leis sintáticas, configurações imaginárias, redes metafóricas -, a engrenagem da linguagem que fortalece certas representações em detrimento de outras, que produz certos significados e impossibilita outros. Novas palavras devem ser inventadas e usos inéditos devem ser concebidos para as remanescentes (na língua francesa, por exemplo, o plural é do domínio masculino; e palavras valorizadas, como sol ou Deus, são masculinas, ao passo que as femininas são menos importantes). Mas esse não seria o principal motor de transformação do simbólico na proposta de Irigaray: o de maior destaque é o processo de mimesis.

Trata-se de reapresentar, reaplicar às mulheres os estereótipos femininos, de forma que sejam alastrados na qualidade de questão. Incitar a Verdade, "mais e mais cópia do mesmo" - assim 
como homem é mais ou menos a cópia da ideia de homem, como um infinito reflexo no espelho (Irigaray, 1974/1985, p. 291). A imitação perene sustenta o ideal de uma suposta origem, mas algo sempre escapa e indaga justamente se há origem, ou se só há cópias sem um ponto de partida. Pretende-se estimular a repetição das visões degradantes associadas às mulheres, também chamada de processo de alimentar o essencialismo estratégico: por exemplo, se a mulher é ilógica, ela deve falar logicamente (atributo culturalmente masculino) sobre sua "ilogicidade". Ocorre que tais repetições nunca são bem-sucedidas, nem tudo que é dito ou performatizado a respeito da mulher é passível de ser abarcado - ela nunca é aquilo que pode ser expresso daquela maneira, ou é algo a mais. Revelar-se-ia o engodo da superintendência masculina, que determina os pretensos valores identitários empobrecedores das mulheres. "Da especularização para o espelho côncavo, no qual as imagens refletidas do sujeito, suas articulações sejam embrenhadas de transformações paródicas" (Irigaray, 1974/1985, p. 144). Ou seja, a mimesis é a reiteração "irônica" de um atributo negativo destinado à mulher com a intenção de revelar que ela não pode ser reduzida a ele, até que tal correlação seja descartada. Além das repetições discursivas, incita-se o ato, o que guarda muito parentesco com o ato performativo butleriano e sua concepção de paródia de gênero. Com a indução da mimesis, algo não é absorvido, e Irigaray $(1977 / 1985)$ situa aqui o gozo feminino.

Para Irigaray (1977/1985, p. 78), há de se quebrar o espelho fálico que induz especularizações no discurso, destruir o maquinário teórico que tem a "pretensão de produzir uma verdade e um significado que seja excessivamente unívoco”. A ideia não é criar uma lógica feminina discursiva com fins de se opor à masculina, o que só confirmaria e daria ainda mais força ao regime falogocêntrico que opera por binários excludentes e hierarquizantes.

"Esta outra lógica discursiva deixaria de privilegiar o 'próprio' em benefício do 'próximo' não (re)capturado na economia espaço-temporal da tradição filosófica" (Irigaray, 1977/1985, pp. 153-4). Implicaria uma relação diferente com a alteridade, a verdade, o mesmo e a repetição contra a especula(riza)ção do espelho plano, a favor do espelho côncavo, debilitando a exclusividade referencial masculina. A autora requer uma reformulação do espaço e do tempo que atinja um lugar topológico distinto e que presumivelmente daria espaço ao gozo da mulher. Dessa vez, Irigaray menciona os lábios e toque para dar corpo às suas ideias.

Acompanhando seu raciocínio, como transmutar o símbolo fálico? Para ir contra o falogocentrismo que permearia a diferença sexual lacaniana, Irigaray propõe, ironicamente ou não, a simbolização on a metáfora dos dois lábios, que habilitaria a construção de um imaginário feminino, atestando a especificidade das mulheres. Esse símbolo dos dois lábios não regido pela lógica fálica estática seria tributário da pluralidade sexual da mulher - dois lábios reproduzindo seu caráter de abertura e movimento, sempre se tocando, contra a imagem monolítica do órgão masculino. Por meio desse tipo de simbolização, a mulher preconizaria sua autenticidade imaginária e a woman-to-woman language adviria, restituindo seu lugar no discurso e sua posição de sujeito. 
Esse anúncio de outra espécie de simbolização em Irigaray serve de estratégia política, na qual o sarcasmo é fundamental, com fins de desaprumar o estandarte fálico do seu posto de comando e afastar o perigo sempre vivo, segundo ela, de sua equação ao pênis. Seria como adotar um essencialismo feminino com objetivos meramente táticos (lábios da boca-lábios vaginais $=$ mulher $\times$ falo-pênis $=$ homem). Além do mais, não haveria hierarquia entre os lábios, como ativo e passivo, nem seriam orientados pelo olhar, sentido preferencial da trama especular masculina, tal como Irigaray concebe, mas pelo toque.

O tocar-se seria primário, anterior ao ver/ser visto; ao contrário do que se dá com a visão, não segue uma lei totalizadora ou excludente, isto ou aquilo: dois lábios, formando um círculo, permitiriam, por exemplo, a ideia de ser mulher $e$ mãe (Irigaray, 1984/1993, p. 167). Não existiria mestria entre eles, nem disputa. Cabe frisar que não se trata aqui da oralidade freudiana. É algo anterior à formação do sujeito e a qualquer articulação da linguagem; o outro (ainda) não foi tomado como objeto de discurso, precisa a autora.

Irigaray estima que as mulheres são detentoras de múltiplas zonas erógenas, cada uma podendo thes proporcionar um tipo de prazer; e que, por ser exigido delas que se adéquem aos ditames fálicos, tais zonas, e suas diversas possibilidades, passam a ser cerceadas - ou mesmo inexploradas. O sexo da mulher não é "um", os dois lábios projetam o plural, sempre se tocando, rompendo, tal explana Geerts (2010-11, p. 19), a lógica binária falocêntrica que divide o mundo em sujeito/objeto, ativo/passivo, tocante/tocado.

Irigaray refere que a topologia do gozo da mulher tem a ver com o formato dos lábios, sustenta-se em uma lógica que está além dos pares de oposição e que se desvela no tocar. Por fim, pesa que tentar definir a sexualidade feminina é um projeto malogrado: buscar precisões ou forjar identidades seria algo que pressupõe a ordem do ser, sistema de representação metafísico que tem como masculino, o que acaba igualando, em seus termos, outridade e mesmitude, firmando a repetição da alteridade do Mesmo nos moldes do eu, "ao que ela responde: não... ainda (em francês encore). E de fato, em um sentido, nesse sentido, nunca" (Irigaray, 1974/1985, p. 232).

Ainda como forma de alimentar todo esse debate, podemos perguntar o que há por trás da proposta de postular um "imaginário feminino", tal como se depura em Irigaray. Não seria autocontraditório? Se se pondera que imaginário e identidade têm parentesco, proclamar um imaginário feminino seria próximo a conceber uma identidade feminina, o que cai na armadilha falogocêntrica de edificação de identidades: tratar-se-ia de uma definição masculina do feminino. Nesse sentido, Irigaray infere que

À mulher não é possível atribuir um significado fixo pelo discurso de forma a lhe imputar um conceito ou alguma noção fixa. Mulher não é relacionada a um ser simples e designável, sujeito ou entidade. Nem é um grupo completo/inteiro [chamado] mulheres. Uma mulher + uma mulher + uma 
mulher nunca será somada para compor uma entidade genérica: mulher. A/uma mulher se refere ao que não pode ser definido, enumerado ou formalizado. (Irigaray, 1974/1985, p. 229, trad. nossa)

O que nos autoriza irmos além: o imaginário feminino pode ser equacionado ao inconsciente do pensamento ocidental, não simbolizado pela Filosofia, restos, fragmentos da estruturação imaginária da ordem simbólica masculina dominante, segundo Whiford (1991). Não estaríamos falando do "inconsciente feminino", mas de como o registro imaginário poderia transformar o registro simbólico - um não tem como ser perscrutado sem o outro - e, a partir daí, seguindo a comentadora de Irigaray, mudar a fantasia social outorgada às mulheres e suas encarnações concretas.

Costuma-se dizer que o simbólico, dentre outras funções (entrada no social, na linguagem, constituição do sujeito e do campo do desejo), faculta a ruptura com o imaginário. Mas, “O simbólico que vocês impõem como universal, livre de qualquer contingência empírica ou histórica, é o imaginário de vocês transformado numa ordem, uma ordem social" (Irigaray, citada por Whitford, in Brennan,1997, p. 161). Ou seja, o problema não seria o simbólico em si, mas como o falogocentrismo ocidental (e a Psicanálise lacaniana) moldaria o simbólico. Como o imaginário masculino acabaria por defrontá-lo e formatá-lo. Nessa interpretação, para Withford (in Brennan, 1997, p. 160), a proposta de Irigaray seria a reconfiguração do simbólico via imaginário: revertendo as fantasias sociais conferidas às mulheres, as representações e o lugar que ocupam no simbólico seriam deslocados.

[...] para Irigaray, é improvável que 0 simbólico, ou seja, aquela ruptura com o imaginário na qual o indivíduo é capaz de pensar sobre seu próprio imaginário, em vez de pensar por ele, tome uma forma social enquanto não existir outro real. No momento, segundo Irigaray, o que temos é uma economia do semelhante, um intercâmbio entre homens - o mesmo imaginário, masculino, sem coisa alguma para atuar como "ruptura", exceto as mulheres. Ou seja, para que os homens façam a ruptura com o imaginário deles, seria necessário outro termo - a mulher como simbólico. Enquanto as mulheres continuarem a ser dentro daquele imaginário, elas não podem ser o termo que efetua a ruptura. (Whiford, in Brennan, 1997, pp. 162-163)

No pensamento de Irigaray, a mulher engendraria uma diferença diferente. A mulher a ser o emblema da différance derridiana. A mulher celebraria a ruptura. Quando? Onde isso já aparece? Onde se lê. $\mathrm{Na}$ "escrita feminina". Se as reivindicações feministas passam necessariamente pela posse do seu corpo e pelo direito de decidir sobre ele, o "Movimento da escrita feminina" quer fundar um tipo de escrita que injete o mais visceral e próprio da mulher, sua experiência de gozo imponderável, na linguagem, a ser convulsionada.

Irigaray (1977/1985, p. 91) comenta a representação do gozo feminino que se dá a ver na estátua de Bernini de Santa Teresa, que ilustra 
a capa do Seminário XX de Lacan: "Em Roma, tão longe, uma estátua, feita por um homem? Feita para ser olhada? Para saber do gozo de Teresa, talvez seja melhor recorrer a seus escritos. Mas como lê-la quando se é homem?”.

A escrita feminina derrocaria a ligeira identificação da mulher com o buraco do discurso, e a estratégia decidida não seria reverter o domínio masculino, movimento esse que só robusteceria o falogocentrismo, mas de praticar a diferença orientada a partir do interior de outro sistema.

Falar (como) mulher (parler-femme) e escrever (como) mulher. A escrita necessariamente provoca outra economia do sentido. Alterando a forma de escrita ou o discurso lógico, aposta Irigaray, outros significados seriam conferidos às mulheres. "[...] o feminino é sempre afetado por e para o masculino. O que queremos pôr em jogo é uma sintaxe pela qual as mulheres possam se autoafetar" (Irigaray, 1977/1985, p. 132). Autoafetar e tocar-se são correlatos a modos de significação em conformidade com o não fechamento feminino, que, em seus termos, consagram-se a desmontar a sintaxe da língua e avistar outra gramática da cultura.

\section{Referências}

Fink, B. (1998). O sujeito lacaniano: entre a linguagem e o gozo. Rio de Janeiro: Jorge Zahar Ed.

Freud, S. (2010). Sexualidade feminina (Vol. XVIII, P. C. de Souza, Trad.). São Paulo: Companhia das letras. (Trabalho original publicado em 1931).
Gallop, J. (1982). The Daughter's Seduction Feminism and Psychoanalysis. Ithaca: Cornell University Press.

Geerts, E. (2010-11). Luce Irigaray: the (Un)Dutiful Daughter of Psychoanalysis a Feminist "Moving through and beyond" the Phallogocentric Discourse of Psychoanalysis. Recuperado em 29 março, 2014, de https://www.academia.edu/403078/Luce _Irigaray_the_un_dutiful_daughter_of_ps ychoanalysis._A_feminist_moving_throug h_and_beyond_the_phallogocentric_disc ourse_of_psychoanalysis

Grosz, E. (1989). Sexual Subversions: Three French Feminists. Australia: Allen \& Unwin.

Irigaray, L. (1973). Le langage des déments. Paris: Mouton / De Gruyter.

Irigaray, L. (1985). Speculum of the Other Woman (G. C. Gill, Trad.) Ithaca: Cornell University Press. (Trabalho original publicado em 1974).

Irigaray, L. (1985). The Sex which Is not One. (C. Porter \& C. Burke, Trad.) Ithaca: Cornell University Press. (Trabalho original publicado em 1977).

Irigaray, L. (1993). An Ethics of Sexual Difference (C. Burke \& G. C. Gill, Trad.) Ithaca: Cornell University Press. (Trabalho original publicado em 1984).

Irigaray, L. (1997). O gesto na Psicanálise. In T. Brennan (Org.). Para além do falo: uma crítica a Lacan do ponto de vista da mulher (pp.171186). Rio de Janeiro: Record / Rosa dos tempos.

Jardine, L. (1997). A política da impenetrabilidade. In T. Brennan (Org.). 
Para além do falo: uma crítica a Lacan do ponto de vista da mulher (pp. 91-102). Rio de Janeiro: Record / Rosa dos tempos.

Lacan, J. (1964-65). Problemas cruciais para a Psicanálise. Publicação não comercial centro de estudos freudianos do Recife.

Lacan, J. (1966-67). Le séminaire, livre XIV Logique du fantasme [Versão Stafela]. Recuperado em 16 abril, 2015, de http://staferla.free.fr/S14/S14\%20LOGI QUE.pdf

Lago, M. C. de S. (2012). A Psicanálise nas ondas dos feminismos. Recuperado em 27 março, 2014, de https://repositorio.ufsc.br/bitstream/han dle/123456789/1350/a_psicanalise_nas_ ondas.pdf? sequence $=1$

Whitford, M. (1991). The Irigaray Reader. Malden/Oxford: Blackwell Publishers Ltda.

Whitford, M. (1997). Releitura de Irigaray. In T. Brennan (Org.). Para além do falo: uma crítica a Lacan do ponto de vista da mulher (pp.145170). Rio de Janeiro: Record / Rosa dos tempos.

Recebido em: 01/08/2017

Aprovado em: 15/08/2018 